\title{
An integrated assessment framework for land subsidence in delta cities
}

\author{
T. H. M. Bucx, C. J. M. van Ruiten, G. Erkens, and G. de Lange \\ Deltares, Delft, the Netherlands \\ Correspondence to: T. H. M. Bucx (tom.bucx@ deltares.nl)
}

Published: 12 November 2015

\begin{abstract}
In many delta cities land subsidence exceeds absolute sea level rise up to a factor of ten by excessive groundwater extraction related to rapid urbanization and population growth. Without change, parts of Jakarta, Ho Chi Minh City, Bangkok and numerous other delta (and coastal) cities will sink below sea level. Increased flooding and also other widespread impacts of land subsidence result already in damage of billions of dollars per year.

In order to gain insight in the complex, multi-sectoral aspects of subsidence, to raise awareness and to support decision making on appropriate adaptation strategies and measures, an Integrated Assessment Framework (IAF) for subsidence is introduced, illustrated by several (delta) case studies. Based on that a list of 10 generic key issues and possible solutions is presented in order to further develop and support a (generic) approach how to deal with subsidence in current and future subsidence-prone areas. For exchange of experiences and knowledge development.on subsidence in deltas the Delta Alliance, a knowledge network of deltas worldwide, can be supportive.
\end{abstract}

\section{Introduction}

In many coastal and delta cities land subsidence exceeds absolute sea level rise up to a factor of ten. A major cause of this severe land subsidence is excessive groundwater extraction due to rapid urbanization and population growth. Current global mean absolute sea level rise is around $3 \mathrm{~mm}_{\text {year }}{ }^{-1}$ and projections until 2100 based on IPCC scenarios expect a global mean absolute sea level rise in a range of 3$10 \mathrm{~mm}$ year $^{-1}$ (Slangen et al., 2012, 2014). However current observed subsidence rates in coastal megacities are in the range of 6-100 $\mathrm{mm} \mathrm{year}^{-1}$ and projections till 2025 expect similar subsidence rates, depending on future measures. This is illustrated in Fig. 1. Without action, parts of Jakarta, Ho Chi Minh City, Bangkok and numerous other coastal cities will sink below sea level.

Land subsidence causes increased flooding and widespread impacts on roads, embankments, subsurface infrastructure and housing, resulting already in damage of billions of dollars per year. In order to gain insight in the complex, multi-sectoral aspects of subsidence, to raise awareness and to support decision making on appropriate adaptation strategies and measures, an Integrated Assessment Framework for subsidence is introduced, illustrated by several (delta) case studies addressing causes, impacts and responses.

\section{Case study results}

In the Greater Jakarta area, metropolitan authorities and technical agencies are advocating the reduction of groundwater extraction in vulnerable areas by completely phasing out the use of groundwater and taxing groundwater consumption. This would include the development of alternative water supply for large industrial users or relocation of large groundwater users, outside the "critical zones". The number of "unregistered" users is still a problem. Ongoing economic development and city expansion, lead to the filling of low-lying and flood prone lands with mineral aggregates and often waste materials. To some extent, spatial planning measures were applied to avoid subsidence-prone areas, but fast growth of informal settlements has made many of these plans obsolete (Dam, 2012). 


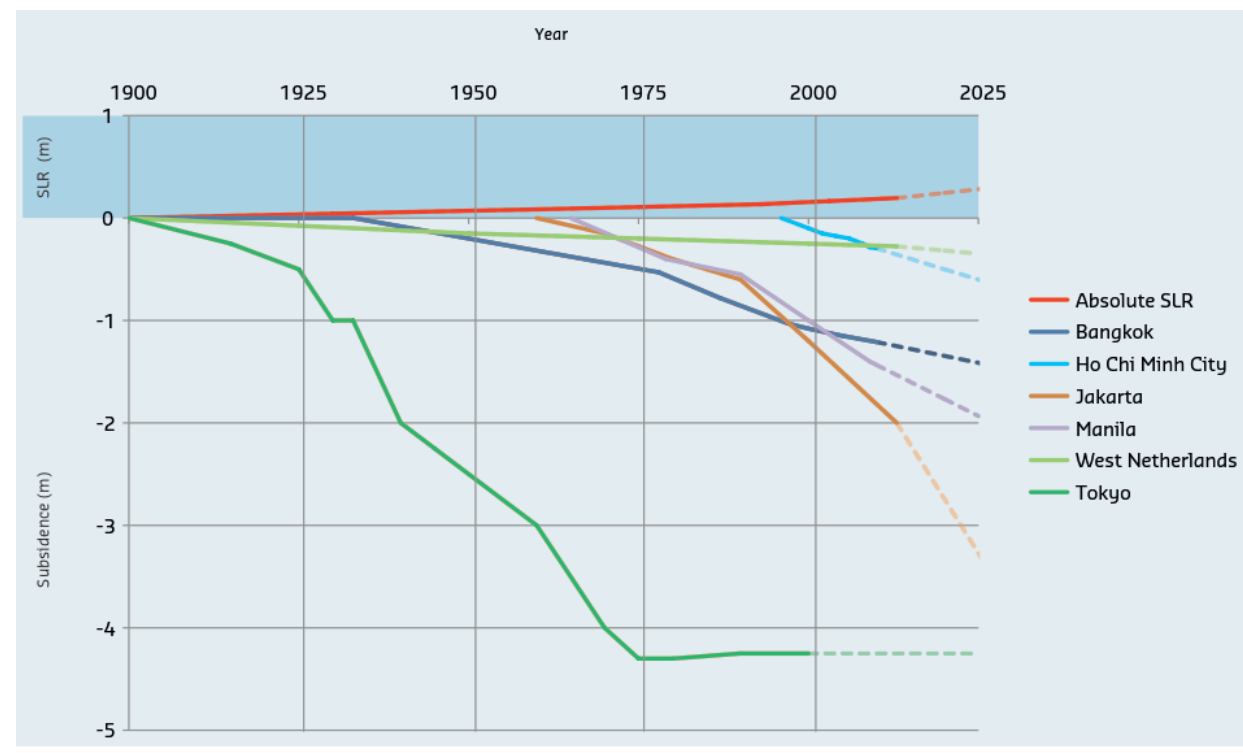

Subsidence in Sinking Cities

\begin{tabular}{|l|c|c|c|c|}
\hline & $\begin{array}{c}\text { Mean cumulative } \\
\text { subsidence in period } \\
1900-\mathbf{2 0 1 3}(\mathbf{m m})\end{array}$ & $\begin{array}{c}\text { Mean current } \\
\text { subsidence rate } \\
(\mathbf{m m} / \mathbf{y r})\end{array}$ & $\begin{array}{c}\text { Maximum } \\
\text { subsidence rate } \\
(\mathbf{m m} / \mathbf{y r})\end{array}$ & $\begin{array}{c}\text { Estimated additional mean } \\
\text { cumulative subsidence } \\
\text { until 2025 (mm) }\end{array}$ \\
\hline Bangkok & 1250 & $20-30$ & 120 & 190 \\
\hline Ho Chi Minh City & 300 & Up to 80 & 80 & 200 \\
\hline Jakarta & 2000 & $75-100$ & 179 & 1800 \\
\hline Manila & 1500 & Up to 45 & 45 & 400 \\
\hline New Orleans & 1130 & 6 & 26 & $>200$ \\
\hline Tokyo & 4250 & Around 0 & 239 & 0 \\
\hline West Netherlands & 275 & $2-10$ & $>17$ & 70 \\
\hline
\end{tabular}

Sea level rise (SLR)

\begin{tabular}{|l|c|c|c|c|}
\hline & $\begin{array}{c}\text { Cumulative mean } \\
\text { SLR in period 1900 - } \\
2013(\mathrm{~mm})\end{array}$ & $\begin{array}{c}\text { Current rate } \\
(\mathrm{mm} / \mathrm{yr})\end{array}$ & $\begin{array}{c}\text { Maximum rate } \\
(\mathrm{mm} / \mathrm{yr})\end{array}$ & $\begin{array}{c}\text { Possible additional future } \\
\text { SLR until 2025 (mm) }\end{array}$ \\
\hline Worldwide mean & 195 & 3 & - & 86 \\
\hline
\end{tabular}

Sources: Bangkok: MoNRE-DGR 2012; Ho Chi Min City: Le Van Trung \& Ho Tong Minh Dinh, 2009; Jakarta: Bakr 2011; Manila: Eco et al 2011; West Nederlands; Van de Ven 1993; Tokio: Kaneko \& Toyota 2011; Church and White, 2011, Slangen et al., 2013

Figure 1. Global sea level rise (SLR) and average land subsidence for several coastal cities (please note that subsidence can differ considerably within a city area, depending on groundwater level and subsurface characteristics).

Recently the Jakarta Coastal Defense Strategy (JCDS) programme integrated the results of various subsidence studies and tried to obtain a reliable number for current and future subsidence trends. This subsidence prognosis is regarded as an extremely vital component for an integrated flood management and coastal defense strategy, but so far a sufficiently detailed hydrogeological model is lacking to reliably predict long term scenarios. This is now under construction (Aobpaet, 2013; Phisut, 2012).

In Bangkok extreme land subsidence by groundwater extraction was successfully reduced by regulations and restric- tions for groundwater extraction. A specific law (Groundwater Act) was enacted in 1977. Most severely affected areas were designated as Critical Zones with more control over private and public groundwater activities. Groundwater Use Charges were first implemented in 1985 and gradually increased. In Bangkok currently about $10 \%$ of the total water use is from groundwater extraction, however subsidence is still ongoing but at a much slower pace than before.

Although land subsidence in Ho Chi Minh City has been observed since 1997, there is still considerable discussion about its causes and impacts (Bakr et al., 2013). This is 
partly due to poor monitoring data on land subsidence and on groundwater extraction. Restrictions on groundwater extraction have been initiated but it is too early to observe effects. Besides the registered exploitation, which draws mainly from the deeper aquifers there is a large amount of unregistered extraction for domestic water supply. Hence, the total drawdown rate shows no sign of decreasing. Possibly, this can also be attributed to the fact that recharge is hindered by the reduction in infiltration area due to urbanization.

In New Orleans and the Mississippi delta there is as yet no coordinated strategy on mitigating subsidence. The extraction of oil and gas is of great economic importance for the region and will be stimulated, rather than limited. The debate on groundwater use in New Orleans has only recently started, as its contribution to subsidence is so far unknown (Dokka, 2011). The recently published water management strategy for New Orleans, however, suggests raising water levels in areas with organic rich soils, reducing oxidation of organic matter and mitigating subsidence. The Mississippi delta is starved of sediment because of constructions of dams and erosion-prevention measures upstream in the catchment. In the Coastal Masterplan for the Mississippi Delta plans are included to reintroduce sediment-loaded floodwaters to the delta once more.

In Tokyo, after taking regulatory measures on restriction of groundwater use in the early sixties, the groundwater levels increased again and after around 10 years the subsidence was stopped (see Fig. 1).

With increasing insight in the relationship between groundwater extraction and land subsidence, techniques were developed in Shanghai to restore groundwater levels with active or passive recharge. Although this reduced the further lowering of groundwater tables and limited subsidence, it did not solve immediate problems, notably the effect of subsidence on infrastructure, roads and buildings. The subsidence rate was $39.1 \mathrm{~mm}_{\text {year }}{ }^{-1}$ during the period of 1921-1965 as a result of the increasing utilization of groundwater for industry development. Since the government began to control extraction and to recharge groundwater after 1965, the rate of land subsidence decreased to $6.2 \mathrm{~mm}$ year $^{-1}$ on average until 2007 (Shi et al., 2008). According to Gong (2008), the primary cause of land subsidence in downtown is construction of high-rise buildings (60\%) after 1990 while in suburbs $70 \%$ is attributed to withdrawal of groundwater.

In Dhaka, increasing problems with flooding and water supply are resulting in more attention to excessive groundwater extraction and subsidence. In this rapidly expanding city many areas are subsidence-prone but there is currently a lack of data on subsidence and its impacts (Steckler et al., 2012). At present around $87 \%$ of the supplied water is from ground water extraction and it has been acknowledged that the focus has to be changed to using surface water instead. However, treating surface water is much more technically complex and expensive than using groundwater, also because the large rivers nearest to Dhaka city, are polluted among others by the economically important textile industry.

While subsidence in large urban environments in deltaic regions can usually be associated with groundwater extraction, in the case of the Netherlands, where deep extractions are rare, centuries of drainage of surface water, often from former peat marshes has resulted in the widespread lowering of the landsurface by several metres. This is exacerbated by the historic exploitation of peat for fuel, leaving large areas below sea level. These areas were reclaimed and converted in fertile clay polders, but require constant drainage of upwelling groundwater from the underlying confined aquifers. Although the recent upconing of brackish water in these polders poses a water management challenge to adapt to these changing environmental and agricultural circumstances, the area where the surficial and shallow peat remained poses the greatest problems (Cuenca et al., 2010). Not only does the oxidation of drained peat produce a significant amount of green house gas, the continuing subsidence in these areas leads to larger areas where the volumes of upwelling water become a significant economical cost factor. Here also the risk of upconing of brackish groundwater is looming in the background. The greatest cost factor however has been shown to be the gradual deterioration of foundations and infrastructure.

In recent years studies have been performed on how to mitigate this situation. In the agricultural areas keeping the drainage level as high as possible has reduced the rate of subsidence considerably. In urban areas in the peat areas, this would only worsen the situation as the settling surface of streets and gardens leaves insufficient freeboard to accommodate heavy rains. In 2014 the summer rains were especially heavy and widespread flooding has triggered a research effort to systematically mitigate the settlement in urban areas on soft soils. Results from analyses combining InSAR monitoring with geological information indicate that damage in urban areas is dominated by the settlement caused by the use of surcharge in the urban developments. Subsidence rates of 10 mm year $^{-1}$ over a decade are not uncommon in these areas, which is comparable to the rates incurred by peat oxidation. Research efforts will therefore concentrate on ways to reduce the load on the soft soils while at the same time improve the drainage capacity of the urban environment.

\section{Costs of subsidence}

Subsidence leads to direct and indirect damage. Direct effects are for instance loss of functionality or integrity of structures like buildings, roads and underground utility networks (critical infrastructure). The most common indirect effects of damage are related to changes in relative water levels, both groundwater levels and surface water levels. The estimation of associated costs is very complex. Moreover due to economic and urban development the potential damage costs 
will increase considerably, especially in subsidence prone areas such as flood plains.

In practice operational and maintenance costs are considered in several short and long term policies and budgeting. The costs appear on financial sheets as ad hoc investments or planned maintenance schemes, but not as damage costs related to subsidence.

In China the average total economic loss due to subsidence is estimated at around USD 1.5 billion year $^{-1}$ of which $80-90 \%$ are indirect losses. In Shanghai, over the period 2001-2010, the total loss cumulates to approximately USD 2 billion. In Bangkok many private and public buildings, roads, pavements, levees and underground infrastructure (sewerage, drainage) are severely damaged by subsidence, but proper estimates of the costs of damage are not available.

In 2006, the total costs of subsidence related damage in the Netherlands was estimated at over EUR 3.5 billion year $^{-1}$. The majority of these costs will not be recognized directly as damage due to subsidence. Also the construction site preparation and construction costs in soft-soil areas should be considered as subsidence-related costs, as these are mainly incurred to prevent consolidation. The greater cost of maintenance of existing structures and buildings as well as the extra costs involved in ground improvement in new developments compared to areas without peat in the subsurface has led to a national governmental fund for municipalities in this situation. A recent inventory of the extra costs incurred in the Netherlands in urban areas and on infrastructure estimated at least EUR 220 million year $^{-1}$. This is excluding damage to historic wooden foundations. A maximum total amount of EUR 40 billion was estimated as cost incurred by soft soil conditions, including projected effects of climate change, when no mitigation measures are taken to counteract present and future adverse conditions.

\section{Integrated assessment framework}

Land subsidence is often literally a "hidden" issue. Because of its complex, cross-sectoral nature it not only takes place out-of-sight, but it is usually not fully recognized (or acknowledged), especially in the domain of governance and institutional mandates and responsibilities (i.e. lack of a responsible problem owner). The detrimental effects of subsidence are ignored until they become a serious and costly issue. If proper attention is paid to developing the required technical, administrative and institutional capabilities, the negative impacts of land subsidence can be mitigated and the process largely stopped. Therefore a comprehensive and integrated approach is needed. Deltares has developed an Integrated Assessment Framework addressing all aspects of subsidence, which can be applied on any subsidence case. It is based on the DPSIR approach (Driving forces, Pressures, State, Impacts and Responses) and Spatial Layer model. The
DPSIR aspects cover the cause-effect-response chain being elaborated for three spatial layers: the Occupation layer (land and water use), Network layer (infrastructure) and Base layer (natural resources subsurface). The main steps and elements of this approach are elaborated in Table 1.

Every city that wants to tackle its subsidence problem has to deal with questions such as: what are the main causes, how much is the current subsidence rate and what are future scenarios, what are the impacts and risks, how can adverse impacts be mitigated or compensated for, and who is involved and responsible to act? In order to answer these technical and governance questions, an integrated approach supports the (policy) development path that cities should follow, from problem identification to planning and implementation of solutions and their evaluation. Every subsiding city is somewhere along this development path (see Table), ranging from being in an early analysis stage (for instance Dhaka, Bangladesh) to cities that more or less seem to have solved the problem at the other end of the spectrum (for instance Tokyo, Japan).

\section{Delta Alliance - knowledge platform}

To address subsidence in delta cities through an integrated approach, the Delta Alliance can be supportive in information gathering, exchange of experiences and knowledge development (joint research initiatives), building on the Delta Alliance publication "Comparative assessment of the vulnerability and resilience of deltas - Extended version with 14 deltas, Synthesis report" (see www.delta-alliance.org).

Delta Alliance is an international knowledge-driven network organization with the mission of improving the resilience of the world's deltas. With increasing pressure from population growth, industrialization, changing climate and subsidence, it is more important than ever that these valuable and vulnerable locations increase their resilience to changing conditions. Delta Alliance brings stakeholders involved in delta management together in order to benefit from each other's experience and expertise and as such contribute to an increased resilience of their delta region, building on scientific research and practical experiences.

Delta Alliance has sixteen network wings where activities are focused: California Bay (USA), Ciliwung and Mahakam (Indonesia), Mekong (Vietnam), RhineMeuse (the Netherlands), Nile (Egypt), Pantanal (Brazil), Ganges-Brahmaputra (Bangladesh), Mississippi (USA), Yangtze (China), Parana (Argentina), Taiwan, (Zambezi) Mozambique, (Tana) Kenya, Ghana, (Ebro) Spain and (Ayeyarwadi) Myanmar. Some other deltas have shown keen interest to join the Delta Alliance network, notably from Senegal, Thailand, Japan, Romania, Benin and Nigeria.

Research and investment in addressing the unique challenges of river delta regions are happening in many projects and programs around the world. Delta Alliance provides a framework to support the symbiosis of these countless activ- 
Table 1. The main steps and elements of the Integrated Assessment Framework for subsidence.

\begin{tabular}{|c|c|c|c|c|}
\hline Steps & Questions & Technical aspects & Governance aspects & $\begin{array}{l}\text { City example } \\
\text { (state of development) }\end{array}$ \\
\hline $\begin{array}{l}\text { 1. Problem } \\
\text { analysis }\end{array}$ & $\begin{array}{l}\text { - How much subsidence is there? } \\
\text { - What are the causes? } \\
\text { - Who is involved and responsi- } \\
\text { ble? }\end{array}$ & $\begin{array}{l}\text { - Measurement data collection } \\
\text { - Data analyses to disentangle } \\
\text { subsidence causes } \\
\text { - (Inverse) modeling to make pre- } \\
\text { dictions }\end{array}$ & $\begin{array}{l}\text { - Awareness raising } \\
\text { - Stakeholder analysis/ } \\
\text { identification of problem owners }\end{array}$ & $\begin{array}{l}\text { - Dhaka } \\
\text { - Manila } \\
\text { - New Orleans } \\
\text { - Jakarta }\end{array}$ \\
\hline 2. Planning & $\begin{array}{l}\text { - How much future subsidence is } \\
\text { predicted? } \\
\text { - What are the current and future } \\
\text { impacts (monetised)? } \\
\text { - What are most vulnerable areas? } \\
\text { - What are possible solutions? }\end{array}$ & $\begin{array}{l}\text { - Scenario constructions } \\
\text { - Modeling/forecasting } \\
\text { - Damage assessments } \\
\text { - Vulnerability and risk } \\
\text { assessments } \\
\text { - Decision support systems } \\
\text { (see 4.6) } \\
\text { - Cost-benefit analyses/multi- } \\
\text { criteria analysis } \\
\text { - Selection of structural measures } \\
\text { in an integrated multi-sectoral } \\
\text { perspective }\end{array}$ & $\begin{array}{l}\text { - Capacity building/education } \\
\text { - Multi-sectoral planning, partici- } \\
\text { pation, stakeholder engagement } \\
\text { and commitment (see } 4.4 \text { and } \\
4.5 \text { ) } \\
\text { - Political action, development of } \\
\text { policy, strategy and legal instru- } \\
\text { ments } \\
\text { - Planning and design of buildings } \\
\text { and infrastructure, incl. building } \\
\text { codes (see } 4.8 \text { ) } \\
\text { - Decision-making on implemen- } \\
\text { tation (see } 4.5 \text { ) }\end{array}$ & - HCMC \\
\hline $\begin{array}{l}\text { 3. Implementa- } \\
\text { tion }\end{array}$ & $\begin{array}{l}\text { - What will be done, how and } \\
\text { when and by whom? }\end{array}$ & $\begin{array}{l}\text { - Installing monitoring systems } \\
\text { (see 4.7) } \\
\text { - Setting up pilot projects } \\
\text { - Proposing innovative (alterna- } \\
\text { tive) solutions (see } 4.3 \text { ) } \\
\text { - Implementation of structural } \\
\text { mitigating and/or adapting } \\
\text { measures (see 4.1, 4.2, 4.3) } \\
\text { - Exchange of knowledge and } \\
\text { best practices (see } 4.10 \text { ) }\end{array}$ & $\begin{array}{l}\text { - Multi-sectoral coopera- } \\
\text { tion/organisational structure } \\
\text { - Implementation of non- } \\
\text { structural measures (see 4.1) } \\
\text { - Legal framework/operational } \\
\text { procedures/guidelines } \\
\text { - Enforcement of laws and regula- } \\
\text { tions } \\
\text { - Financing mechanisms/asset } \\
\text { management (see 4.9) }\end{array}$ & - Bangkok \\
\hline 4. Evaluation & - Is the problem under control? & $\begin{array}{l}\text { - Monitoring, re-modeling } \\
\text { - Compliance checking } \\
\text { - Assessment and outlook }\end{array}$ & $\begin{array}{l}\text { - Stakeholder evaluations } \\
\text { - Public hearing }\end{array}$ & $\begin{array}{l}\text { - Tokyo } \\
\text { - Shanghai }\end{array}$ \\
\hline
\end{tabular}

ities ongoing in delta regions, reducing unnecessary overlap and identifying gaps in efforts. Delta Alliance is a vehicle for increased cooperation between parties in river deltas worldwide, with the ultimate aim of improving the resilience of the world's deltas through more integrated and effective efforts, building on scientific research and knowledge exchange.

The members of Delta Alliance together develop and share knowledge to:

- envision resilient deltas

- measure, monitor and report resilience in deltas, and

- provide inspiration and support for improved resilience in deltas
In pursuing these goals, members strive to:

- share knowledge, expertise and best practices between deltas worldwide

- co-create and integrate knowledge across deltas, sectors and disciplines

- connect expertise and parties from throughout the watershed

- incorporate local knowledge in research and other knowledge-building activities 
- provide knowledge and insight to support any use, including education, policy development, investments and disaster response.

The Delta Alliance has many linkages with other networks and initiatives such as the Global Water Partnership strategy 2014-2018, the Belmont Forum Deltas project, the GEF Transboundary Waters Assessment Programme, the Alliance for Global Water Adaptation, and the SIWI/UNEP initiated From Source to Sea partnership. This is further supported by the Sustainable Deltas Initiative 2015 as endorsed by ICSU.

One of the most important research activities of the Delta Alliance in the past years was a comparative assessment of the vulnerability and resilience of 14 deltas, addressing various aspects of delta development and management through an integrated approach. The following deltas were involved: Nile, Tana, Incomati, Zambezi, Ganges- BrahmaputraMeghna, Yangtze, Ciliwung, Ayeyarwady, Mekong, RhineMeuse, Danube, San Francisco Bay and Delta, Mississippi River and Parana. In this study subsidence was recognized as an important issue to be dealt with in many deltas.

\section{Conclusions and the way forward}

As yet, insufficiently are taken into account natural resource management, regional (urban) development and strategic spatial planning, and in particular urban flood management, infrastructure design and infrastructure maintenance.

In the framework of an integrated approach the following 10 generic key issues and possible solutions should be further elaborated on a case by case basis:

\subsection{Restriction of groundwater extraction}

This measure is very important in most cases to counteract human induced subsidence. In vulnerable areas extraction of groundwater should be reduced or completely phased out.

The following regulatory measures can be considered:

- appropriate legislation and consistent implementation and enforcement of regulations

- designation of groundwater regions and critical zones

- restricted licensing and compliance checking for groundwater well drilling

- universal groundwater use metering and charges for groundwater use

\subsection{Development of alternative water supply (instead of groundwater)}

In order to fulfill the increasing (urban) water demand, an alternative water supply for industry and domestic users is required. This process should include water demand assessments (water footprint) and cost/benefit assessments. Addressing and reducing surface water pollution is vital, to develop a sustainable alternative water supply.

\subsection{Natural and artificial recharge of aquifers}

When addressed consistently and effectively, the reduction of groundwater mining can eliminate one of the primary causes of land subsidence. However, the prolonged effects of settlement, possibly taking up to 10 years, are not immediately solved. Natural and/or controlled groundwater recharge may be applied to speed up recovery, as well as controlled aquifer storage and recovery (ASR) as currently being developed and implemented in Shanghai and Bangkok.

\subsection{Integrated (urban) flood water management}

Improved groundwater management and subsidence studies should be part of an integrated urban water (resources) management strategy including the whole water-subsurface system. Water resources management should be linked to flood mitigation. Ultimately, land subsidence is intricately linked to integrated land and water management, including surface as well as subsurface resources and constraints.

\subsection{Improving governance and decision-making}

In many cases governance is inadequate to address subsidence in an integrated multi-sectoral approach and to develop sustainable short and long term solutions. This involves (public) awareness, encouraging (public) participation, cooperation and coordination between stakeholders at different scales and levels, and also enabling good decision-making supported by decision support models and tools.

\subsection{Decision support models and tools}

Development of models and tools are important to support good decision-making. This involves among others analysis of the relationship between groundwater level and subsidence, development of modeling and forecasting capabilities by development and implementation of an integrated groundwater-subsidence monitoring and analytical model. Moreover, it is essential that local agencies have the expertise and tools to conduct studies, and are engaged in ongoing capacity building, training and knowledge exchange.

\subsection{Appropriate monitoring and database system}

Ongoing studies show that the dependence on reliable ground truth data of observed subsidence is an alarming "Achilles heel" in the battle against subsidence and related flood risk. Therefore, it is necessary to develop and maintain geodetic monitoring networks throughout the metropolitan areas, with stable, precisely calibrated benchmarks levels and periodic 
leveling surveys, in order to build a good database with long time measurements of subsidence.

\subsection{Integrating geotechnical aspects in planning and design of buildings and infrastructure}

In the planning and design of (heavy) buildings and road infrastructure, geotechnical research and modelling of the subsoil should be taken into account in order to avoid subsidence problems including differential settlements, in the short or long term. This will save considerable damage and high maintenance costs of infrastructure and buildings (foundations). During underground construction activities (deep parking lots, metro-stations, tunneling), the effects of dewatering should be minimized and, if necessary monitored and/or mitigated.

\subsection{Asset management, financing and public-private-partnerships (PPP)}

To minimize damage caused by subsidence, the main financial risks associated with investments and maintenance of assets (buildings, infrastructure) should be assessed. This will lead to improved design options, programming and prioritization of investments, making use of Real Options Theory and Asset Management. This involves determining performance indicators, functional specifications, risk mitigation measures and bonus/malus in (innovative) contracts. Moreover PPP and Private Financing should be explored building on sustainable business models.

\subsection{Exchange of knowledge and best practices}

Through organization of international conferences, workshops, expert meetings and courses knowledge and best practices can be exchanged to extend the common knowledge base efficiently and effectively, especially regarding lessons learned from higly build-up urban areas and rural argicultural areas. This can be further supported by development of collaborative research projects preferably in the framework of international (research) networks and initiatives such as the UNESCO, CCOP and the Delta Alliance.

\section{References}

Aobpaet, A., Cuenca, M. C., Hooper, A., and Trisirisatayawong, I.: InSAR time series analysis of land subsidence in Bangkok, Thailand, Int. J. Remote Sens., 2012.

Bakr, M.: Land subsidence in North Jakarta - preliminary analysis results, part of Jakarta Coastal Defence Strategy (JCDS) study, JCDS Atlas, 2011.

Bakr, M., de Lange, G., and Toan, D. N.: Ho Chi Minh City Flood and Inundation Management - Final Report, Volume 2, IFRM Strategy, Annex 3, Land Subsidence, Royal Haskoning-DHV and Deltares, 2013, HCMC FIM, 9T4178/HCMC/R/0042/MB, 2013.
Church, J. A. and White, N. J.: Sea-Level Rise from the Late 19th to the Early 21st Century, Surv. Geophys., 32, 585-602, doi:10.1007/s10712-011-9119-1, 2011.

Cuenca, M. C., van Leijen, F. J., and Hanssen, R. F.: Shallow subsidence in the Dutch wetlands estimated by satellite radar interferometry, Delft University of Technology, First International Conference on Frontiers in Shallow Subsurface Technology, Session: Shallow Subsurface Characterization, Imaging and Monitoring Techniques I, 2010.

Dam, R.: Jakarta Coastal Defence Strategy (JCDS) study, Activity Report, Land subsidence and adaptation/mitigation strategies, JCDS Bridging Phase, Deltares, 2012.

Dokka, R. K.: The role of deep processes in late 20th century subsidence of New Orleans and coastal areas of southern Louisiana and Mississippi, J. Geophys. Res., 116, B06403, doi:10.1029/2010JB008008, 2011.

Eco, R. C., Lagmay, A. A., Bato, M. P.: Investigating ground deformation and subsidence in northern Metro Manila, Philippines using Persistent Scatterer Interferometric Synthetic Aperture Radar (PSInSAR), American Geophysical Union, Fall Meeting, 2011.

Gong, S.: Synthesis analysis of impact factors for land subsidence and its systematic adjustment in Shanghai, East China Normal University, 2008.

Kaneko, S. and Toyota, T.: Long-Term Urbanization and Land Subsidence in Asian Megacities: An Indicators System Approach, In Groundwater and Subsurface Environments: Human Impacts in Asian Coastal Cities, doi:10.1007/978-4-431-53904-9_13, 2011.

Le Van Trung and Ho Tong Minh Dinh: Monitoring Land Deformation Using Permanent Scatterer INSAR Techniques (case study: Ho Chi Minh City), 7th FIG Regional Conference Spatial Data Serving People: Land Governance and the Environment - Building the Capacity Hanoi, Vietnam, 19-22 October 2009.

Shi, X., Wu, J., Ye, S., Zhang, Y., Xue, Y., Wei, Z., Li, Q., and $\mathrm{Yu}, \mathrm{J}$. : Regional land subsidence simulation in Su-XiChang area and Shanghai City, China, Eng. Geol., 100, 27-42, doi:10.1016/j.enggeo.2008.02.011, 2008.

Slangen, A. B. A., Katsman, C. A., van de Wal, R. S. W., Vermeersen, L. L. A., and Riva, R. E. M.: Towards regional projections of twenty-first century sea-level change based on IPCC SRES scenarios, Clim. Dyn., 38, 1191-1209, doi:10.1007/s00382-011-1057-6, 2012.

Slangen, A. B. A., Carson, M., Katsman, C. A., van de Wal, R. S. W., Köhl, A., Vermeersen, L. L. A., and Stammer, D.: Projecting twenty-first century regional sea-level Changes, Climatic Change May 2014, 124, 317-332, doi:10.1007/s10584014-1080-9, 2014.

Steckler, M. S., Akhter, S. H., Seeber, L., Bilham, R. G., Kogan, M. G., Masson, F., Maurin, T., Mondal, D., Piana Agostinetti, N., Rangin, C., and Saha, P.: GPS Velocities and Structures across the Burma Accretionary Prism and Shillong Anticline in Bangladesh, Fall Meeting, 2012.

Phisut: Technology: The study of systematic land subsidence monitoring on critical groundwater used area project - executive summary (report in Thai), Ministry of Natural Resources and Environment, Department of Groundwater Resources, Bangkok, Thailand, 2012.

van der Ven, G. P.: Man-made lowlands, history of water management and land reclamation in the Netherlands, uitgeverij Matrijs, Utrecht, ISBN-13: 978-9053450307, 1993. 